\title{
Religion
}

\section{Epidemics and Plague in Premodern Chinese Buddhism}

\author{
Joshua Capitanio | ORCID: 0000-0003-3092-352X \\ East Asia Library, Stanford University, Stanford, CA, USA \\ jcapitanio@stanford.edu
}

\begin{abstract}
Buddhist scriptures describe the rise of epidemics as a cosmological inevitability and prescribe a variety of methods for preventing and treating epidemic diseases, which focus mainly on purifying negative karma and exorcizing the supernatural beings responsible for their spread. As these ideas were transmitted to China, Chinese Buddhists assimilated them to indigenous beliefs that also portrayed epidemics as retribution for nonvirtuous behavior, enacted by ghostly agents.
\end{abstract}

\section{Keywords}

epidemic - plague - Buddhism - Chan - repentance - healing - exorcism

Epidemics $(y i$ 疫) were as significant a matter for people in the premodern age as they are in the present day. ${ }^{1}$ Concern over the spread of epidemics and

1 Chinese Buddhist texts use several different terms for rapidly spreading infectious diseases. The primary terms that I have translated here as "epidemic" are $y i$ 疫, $j i$ 疾, and the compounds jiyi 疾疫 / yiji 疫疾 formed from their permutations. For a general overview of 
speculation about how to deal with them is found in texts throughout the Sinitic Buddhist canon, reflecting not only Chinese Buddhists' apprehension but also the worries of Indic and Central Asian Buddhists whose works were translated into Chinese. Many Chinese Buddhist texts thus reflect broader pan-Buddhist discourses. ${ }^{2}$ However, a few Chan 禪 Buddhist texts from approximately the twelfth century onward express concern about another type of highly communicable disease that can be translated as "plague" (wen 瘟). These texts discuss plague according to discourses of etiology and treatment that originated in southern China during the tenth and eleventh centuries. Yet although these paradigms for dealing with plague were deeply rooted in indigenous Chinese beliefs and practices, they remained consistent with Buddhist views that regard epidemics as the product of some combination of karmic retribution and demonic intervention.

\section{Epidemics in Buddhist Cosmology}

According to general Buddhist cosmological beliefs, a rise in epidemics is one of the harbingers of the end of an eon (Ch. jie 劫, Skt. kalpa), the impossibly long period that encompasses the creation and destruction of the entire universe. Different sources provide a variety of schemata for the unfolding of these periods, ${ }^{3}$ but they generally agree that a "major eon" (dajie 大劫) is subdivided into eighty "minor eons" (xiaojie 小劫), comprising twenty minor eons of destruction (sanhuai 散壞), twenty minor eons of abiding subsequent to destruction (sanhuai yizhu 散壞已住), twenty minor eons of formation (qicheng 起成), and twenty minor eons of abiding subsequent to formation (qicheng yizhu 起成已住). During the present period of abiding subsequent to formation, each minor eon is characterized by the rise and decline of human life spans, from ten years at the beginning, to eighty thousand years at its height, and then back down to ten at the end. As the human life span decreases back down to ten years, three so-called "lesser calamities" (xiaozai 小災) will occur, namely, epidemics (jiyi 疾疫), military conflict (daobing 刀兵), and famine (ji'e 飢餓). ${ }^{4}$

epidemics in Chinese history, see Leung 1993; Kuriyama 200o; Needham and Lu 2000, 114-74; Hanson 2011, 7-24.

2 On these pan-Buddhist views of illness and healing, see Demiéville 1985. For more on the Chinese reception of Buddhist medical discourses, see Strickmann 2002; Salguero 2014.

3 For an overview, see Fayuan zhulin 法苑珠林, in Taishō shinshū daizōkyō (hereafter abbreviated as T.) no. 2122, 53:269c27-271c4; La Vallée Poussin 1988, 489-9o; Rahula 2001, 87.

4 This sequence varies from text to text; see Fayuan zhulin, T. no. 2122, 53:270a20-22. 
In discussions of these lesser calamities, two related themes emerge. Although the rise of epidemics is described from one standpoint as a cosmological inevitability, their spread is also connected to the moral failings of the beings of those degenerate times, and effected through the agency of supernatural beings. The Abhidharma Treatise Spoken by the Buddha on the Establishment of the World, translated during the sixth century, describes:

When the minor calamities arise in the first eon of the world's abiding subsequent to formation, a great epidemic and all manner of sicknesses will arise everywhere throughout Jambudvipa. The people of all countries and lands will meet with epidemics. Anger and wickedness will arise in the minds of all ghosts and spirits, and they will harm the people of the age. ${ }^{5}$

Similarly, Vasubandhu's (fl. fourth-fifth century) Treatise on the Treasury of Abhidharma, another sixth-century translation, states that during this final period, "nonhuman beings will spit poison, causing epidemics to spread broadly, and whoever encounters these will perish due to their incurability" 6

This notion of the cosmological inevitability of epidemics is a basic premise of Buddhist cosmology, articulated long before Buddhism spread to China, which is generally accepted by all Buddhist traditions. Thus, although the sources cited above were not translated until the sixth century, the notion of an age of epidemics can be found in texts introduced to China in the third and fourth centuries, if not earlier. ${ }^{7}$ Although the description of epidemics in these sources is specifically connected to Buddhist ideas about the progression of cosmic cycles, many Chinese Buddhists throughout history truly believed that they were living in apocalyptic times, and consequently would have understood the spread of epidemics during their lifetimes as related to these cosmic cycles. ${ }^{8}$ Furthermore, beyond cosmological writings, the idea that epidemics arise as supernatural retribution for unethical conduct appears within many

5 Foshuo lishi apitan lun 佛說立世阿毘晊論, T. no. 1644, 32:215c1-4. Unless otherwise noted, all translations are my own.

6 Apidamojushe lun 阿毘達磨俱舍論, T. no. 1558, 29:66a2-4.

7 For example, the age of epidemics is mentioned in the Discourse on the Great Cosmogony ( $D a$ loutan jing 大樓炭經, T. no. 23) and the Discourse on the Fortunate Eon (Xianjie jing 賢劫經, $T$. no. 425), both translated in the late third century.

8 See Strickmann's study of the Discourse on Consecration (Guanding jing 灌頂經, T. no. 1331), a fifth-century indigenous Chinese composition based on an eclectic range of Indic sources that, advocating many of the prophylactic and curative ritual methods described below, "presents itself as a comprehensive manual of practice for the end of the dharma and clearly demonstrates that, in its author's view, the current age corresponded to the final years of the 
sources, which generally prescribe two ways of dealing with epidemics: purification of negative karma, and exorcizing nonhuman agents of disease. ${ }^{9}$

\section{Epidemics and Karma}

The purification of negative karma is one of the Buddhist practitioner's most basic goals. One way to accomplish this is simply to create positive karma by engaging in meritorious religious practices. In a scripture translated during the fifth century, the Discourse on the Flower of Compassion, the Buddha recounts the story of an aspiring bodhisattva who vows to dispel epidemics in future ages: "During the eon of epidemics, I will teach and convert all sentient beings, causing them all to abide in the six harmonious methods and the four methods of gathering, and thereby all epidemics and sentient beings' ignorance will be eradicated."10 The "six harmonious methods" are six guidelines for living harmoniously with fellow renunciants, and the "four methods of gathering" are techniques for winning others over to Buddhism. Thus this text claims that even basic practices of ethical and altruistic conduct can quell epidemics.

Similarly, simple devotional acts such as reciting and copying scriptures can also protect against epidemics. In a seventh-century translation of the Discourse on the Perfection of Wisdom in 8, ooo Lines, the Buddha states that:

If virtuous men and women are capable of listening attentively, receiving, reciting, studying, and contemplating the perfection of wisdom, copying and explaining it for others, then neither Māra, his retinue, or any other human or nonhuman beings will be able to take advantage of them, and disasters and epidemics will be unable to harm them. ${ }^{11}$

Similar declarations can be found in other texts such as the Most Victorious Kingly Discourse on Golden Light, an early eighth-century translation of which has the Buddha stating that for those who uphold this discourse, "its power will be capable of eradicating all suffering, bandits, famine, and all

doctrine" (Strickmann 1990, 68). For more on Chinese Buddhist apocalypticism, see Zurcher 1982; Nattier 1991.

9 For further details on these views, see Salguero 2014 on karma-based etiologies and Strickmann 2002 on spirit-based etiologies. It should be noted that these ideas were not limited to Buddhists; Shigehisa Kuriyama notes that the dominant themes in traditional Chinese understandings of epidemics were "demons, heavenly displeasure, the attacks of wind and cold, and ... emotional exhaustion" (Kuriyama 2000, 4).

10 Beihua jing 悲華經, T. no. 157, 3:202c26-29.

11 Da bore boluomiduojing 大般若波羅蜜多經, T. no. 220, 7:872b9-12. 
various epidemics."12 These exhortations to uphold, recite, copy, and spread the Buddha's words are common to Mahāyāna discourses. Even when specific applications to epidemics are not mentioned, Buddhists generally understood that merit accrued through such actions could be dedicated toward a variety of positive outcomes, including healing. ${ }^{13}$

Beyond general means of making merit, Chinese Buddhists also undertook specific practices to wipe away the karmic residue of prior transgressions. The most important of these was repentance (chanhui 懺悔). Repentance rituals originated as an element of monthly observances held within monastic communities, but the Mahāyāna scriptures expanded it into an independent ritual practice recommended for both monastic and lay practitioners. ${ }^{14}$ One common form of repentance involved reciting scriptures listing the names of various Buddhas and bodhisattvas. ${ }^{15}$ One of the more well-known of these, the Discourse on the Buddhas' Names, an undated text that can be traced roughly to the Tang dynasty (618-907), contains several brief references to epidemics. Its thirteenth chapter, dealing with the various karmic retributions that occur within the realms of gods and humans, contains such statements as:

We repent all transgressions whose retribution produces winter plagues, summer epidemics, ulcers, and fevers within the human world.... We repent all transgressions whose retribution produces immeasurable calamities, disasters, epidemics, hardships, and distress, now and in the future, among humans and gods.... May all chronic illnesses be forever dispelled from body and mind, and may epidemics, poison, and all disasters never trouble us. ${ }^{16}$

These lines from the Discourse on the Buddhas' Names praying for the amelioration of epidemics were also interpolated within several repentance rites compiled later in the Tang, such as the Compassionate Water Repentance and the Perfect Enlightenment Retreat. ${ }^{17}$

\footnotetext{
12 Jinguangming zuisheng wangjing 金光明最勝王經, T. no. 665, 16:427c2-3.

13 Levering 1989.

14 Kuo 1994.

15 These are T. nos. 425-448b. On the genre of Buddha-name scriptures and related liturgies, see Kuo 1994, 119-47.

16 Foshuo foming jing 佛說佛名經, T. no. 441, 14:236ao2-22. See Kuo 1994, 128-31, for an outline and summary of this text.

17 See, e.g., Cibei shui chanfa 慈悲水懺法, T. no. 1910, 45:978a23-24; Yuanjue jing daochang xiuzheng yi 圓覺經道場修證儀, in Shinsan Dainihon zokuzōkyō (hereafter abbreviated as $X$.) no. $1475,74: 488 \mathrm{c18}-19$.
} 
Not all repentance liturgies include such specific language addressing the causes and effects of epidemics. However, since epidemics were understood to result from karmic transgressions, any general form of repentance could be efficacious in dealing with them. The Continued Biographies of Eminent Monks, compiled in the Tang, relates the story of a monk named Xuanjian 玄 鑒 (d.u.), who is courted by a would-be patron, an official named Zhangsun Yi 長孫義. Yi sends a jug of wine to try to win him over, but Xuanjian breaks the jug and declares that he will not risk destroying his merit by engaging in behavior contrary to Dharma. The official is offended and decides to bring trouble to Xuanjian, but is deterred after dreaming of an armed figure menacing him. Subsequently:

He encountered an epidemic whose vapors caused many deaths. At this, he completely threw himself at [Xuanjian's] mercy. Jian performed a repentance ceremony on his behalf and made him give up alcohol and meat. All those who were sick then recovered fully. ${ }^{18}$

Similarly, the biography of Huisi 慧思 (515-577), known for his diligence in reciting scriptures, relates that "the small hermitage where he lived was burned down by others, and subsequently an epidemic arose. Praying sincerely and seeking repentance, he rebuilt the thatched hut and returned to reciting scriptures as before, and the troubles were pacified."19

In both of these stories, the circumstances that produced the negative karma are identified, and specific remedies are undertaken to address these. The incident with Xuanjian is precipitated by Zhangsun Yi's offer of alcohol, which offends the monk, leading Yi to plot against him. Yi's dream of a menacing saber-wielding figure suggests the involvement of nonhuman beings, and the description of the "epidemic vapors" (yiqi 疫氣) recalls both the Abhidharmic notion of nonhuman beings spitting poisonous vapors during the end times and indigenous Chinese beliefs that equate epidemics with noxious pneumas ( $q i$ 氣) spread by vengeful spirits, discussed further below. After Zhangsun comes clean, Xuanjian performs repentance "on his behalf," but the official is also required to give up meat and wine to atone for the offense of offering alcohol to a renunciant. Similarly, in the story of Huisi the narrative is quite clear: his hut is burned down by unnamed people, and subsequently an epidemic manifests. Therefore, in order to undo the negative karmic effects that its destruction caused and return to the meritorious activities of performing

18 Xu gaoseng zhuan 續高僧傳, T. no. 206o, 50:542a22-b1.

19 Tiantaijiuzuzhuan 天台九祖傳, T. no. 2069, 51:98c9-11. 
repentance and reciting scriptures, he must also rebuild the hut in order to pacify the epidemic.

In these discourses of merit and repentance, epidemics that appear as retribution for immoral acts are pacified by performing positive activities that create merit and purify negative karma. Another common approach is the use of incantations, ${ }^{20}$ which draw upon the compassionate salvific power of Buddhas and bodhisattvas who empower these incantations through their vows to protect sentient beings. Such incantations may be used for healing epidemics and disease in a variety of ways, whether by healing afflicted individuals directly or indirectly (through the application or consumption of enchanted substances), enabling them to create immense merit or pacify great amounts of negative karma, or exorcizing the ghosts and spirits responsible for spreading disease.

\section{Epidemics and Incantations}

The use of incantations to dispel epidemics or heal those afflicted by them is recommended in many scriptures. In a section of the Great Collected Discourses translated during the fifth century that focuses on the bodhisattva Ākāśagarbha 虛空藏菩薩, the Buddha declares that he will offer his audience an incantation that will allow them to request assistance from protective deities, stating:

If one is exiled from the kingdom by the king or his ministers, or becomes seriously ill, or if conflicts regularly arise, or if the kingdom experiences an epidemic, then when such situations arise, you will be able to eliminate them through the power of this incantation before they achieve fruition..$^{21}$

Similarly, in an eighth-century translation of the Discourse on the Merits of the Former Vows of the Brilliant Beryl Medicine Master and the Seven Buddhas, a scripture dedicated to the Buddha Medicine Master (one of the most important healing figures in Mahāyāna Buddhism), ${ }^{22}$ the bodhisattva Manjuśrī asks a cohort of seven Buddhas to deliver

a divine incantation of great power, which can provide all future sentient beings with little merit—whether bound up by illness; facing hardship

\footnotetext{
20 “Incantation” (Ch. zhou 呪/咒), generally encompasses several categories of magical utterances found in Buddhist texts, i.e., vidyā, dhäraṇī, and mantra. See McBride 2005.

21 Da fangdeng daji jing 大方等大集經, T. no. 397, 13:126b9-16.

22 Birnbaum 1979.
} 
due to the movements of the sun, moon, and stars; dealing with epidemics or violence; traveling on dangerous paths; or encountering all manner of frightful circumstances - with a refuge that will bring them peace and security. If those sentient beings write, teach others to write, recite, or explain to others this divine incantation, then they will constantly receive the protection and consideration of all the Buddhas. ${ }^{23}$

In both of these examples, healing is effected through the simple recitation or copying of the incantation, and the pacification of epidemics is just one of many possible positive outcomes that such activities may produce. Other texts provide more specific instructions. For example, the Discourse on the Dhāraṇi of the Thousand-Armed and Thousand-Eyed Bodhisattva Avalokiteśvara (known popularly as the "Great Compassion Dhäraṇı"), translated in the early eighth century, recommends the following procedures:

If epidemics are circulating in the villages, you should make a water mandala four cubits in diameter. Recite the incantation 108 times over some quality curds. Then toss some curds on the fire while reciting the incantation; do this altogether 1,008 times, and all calamities and epidemics will be eliminated. Also, let people afflicted by the epidemic consume a small amount of the curds, and they will soon be cured. ${ }^{24}$

Another procedure involving an incantation of the Eleven-Faced Avalokiteśvara requires the practitioner to apply minerals such as realgar and orpiment to "grasses and leaves," and then recite the incantation over these before an image of the bodhisattva. Afterward, the mineral and plant substances are mixed with warm water, bathing in which will remove all manner of obstacles, nightmares, and epidemics. ${ }^{25}$ Another text recommends reciting an incantation over a vase of water, which is then sprinkled upon the sick person to pacify their epidemic. ${ }^{26}$ Thus although the recitation of incantations is still central, other material elements are required to bring about efficacious results.

All of these rituals feature enchanted objects that are consumed or applied to the patient's body. Other procedures target the agents of epidemics. A

23 Yaoshi liuliguang qifo benyuan gongde jing 藥師琉璃光七佛本願功德經, T. no. 451, 14:416c26-417a3.

24 Qianshou qianyan Guanshiyin pusa lao tuoluoni shen jing 千手千眼觀世音菩薩姥陀羅 尼身經, T. no. 1058, 20:10oc25-29.

25 Foshuo shiyimian Guanshiyin shenzhou jing 佛說十一面觀世音神咒經, T. no. 1070, 20:151b21-24.

26 Bukong juansuo zhoujing 不空羂索呪經, T. no. 1093, 20:401b27-29. 
sixth-century translation of the Discourse on the Incantation of the [Bodhisattva] Unfailing Lasso suggests that "when epidemic strikes the home, or ghosts otherwise trouble the household, you should pick 108 lotus flowers. Recite the incantation over each lotus flower and throw it into the fire, and all will be eliminated."27 The seventh-century Rites of the Most Victorious Dhäranī of the Buddha's Crown recommends a larger-scale procedure:

If people within the kingdom are afflicted by illnesses caused by ghosts, and seasonal epidemics spread, then at the four gates of the city, put pieces of blue paper inscribed with the incantation into white sandalwood boxes, seal them with wax, and place them in front of the city gates. Cover the boxes with five-colored umbrellas at each gate. Epidemics and ghostly illnesses will be eliminated and will not dare to return. ${ }^{28}$

A similar technique involves twirling staves at the four city gates in order to banish the epidemic ghosts who are afflicting the region. ${ }^{29}$ Such methods are more exorcistic, intended to drive the forces causing illness away from the area.

Hagiographical accounts suggest that such incantatory techniques were indeed practiced. One story of the monk Tan Wuchan 昙無驖 (385-433) performing an exorcism on behalf of his patron, the ruler Juqu Mengxun 沮渠蒙 遜 (368-433) recalls some of the methods described above:

Wuchan once told Mengxun that ghosts had entered the region, and would certainly bring disasters and epidemics. Mengxun did not believe this, and wanted to see it for himself. Wuchan used his arts to empower Mengxun, and when Mengxun saw [the ghosts] he became fearful. Wuchan said, "We should sincerely perform a fast ${ }^{30}$ and recite divine incantations to exorcise them." So, he recited incantations for three days, and then told Mengxun, "The ghosts have left." People near the borders saw the ghosts and reported that hundreds of epidemic ghosts had suddenly fled. ${ }^{31}$

Similarly, in the story of the monk Zhu Fakuang 竺法曠 (326-402), the sixthcentury Biographies of Eminent Monks relates that "when an epidemic had

27 Ibid., 20:401c3-5.

28 Foding zunsheng tuoluoni biefa 佛頂尊勝陀羅尼別法, T. no. 974F, 19:397b4-7.

29 Bukong juansuo shenbian zhenyan jing 不空羂索神變真言經, T. no. 1092, 20:295a26-28.

30 The "fast" (zhaijie 齋戒) is a purification ritual related to repentance. See Hureau 2010, $1213-27$.

31 Gaoseng zhuan 高僧傳, T. no. 2059, 336b8-13. 
struck the eastern regions, as Kuang had engaged in some practices of compassion and was skilled with divine incantations, he traveled around throughout the countryside saving people." ${ }^{32}$ Neither of these narratives specify the incantations used. However, there are many accounts of practitioners employing incantations such as the Great Compassion Dhäranī or the incantation of Eleven-Faced Avalokiteśvara for other apotropaic purposes. ${ }^{33}$ Therefore, we can surmise that practitioners familiar with the ritual application of these incantations could have used them to combat epidemics when they arose.

\section{Exorcism and Plagues}

These methods of purifying karma and reciting incantations to address the spread of epidemics were introduced to Chinese Buddhists through translated texts. The adoption of such practices was facilitated in part because indigenous Chinese paradigms for understanding diseases and their treatments shared many similarities with these Indic Buddhist ideas. ${ }^{34}$ The belief that illnesses and epidemics were caused by demonic beings was widespread long before Buddhism was introduced to China. Such supernatural depredations were also regarded as retribution for unethical behavior, and, particularly in Daoist communities, confession, repentance, as well as the use of incantations, talismans, and other ritual devices were recommended as treatment. ${ }^{35}$ One important Chinese religious practice involved the exorcism of spirits associated with the spread of warm-weather plagues on the fifth day of the fifth lunar month, known as the Double Fifth (duanwu jie 端午節), a practice that has continued from antiquity to the present day. ${ }^{36}$

Textual evidence suggests that Chinese Buddhists also performed exorcistic activities to drive away plague demons around the Double Fifth festival. By the Song dynasty (96o-1279), an indigenous Chinese mythology had coalesced around the idea of plague demons, particularly the so-called Five Plague Emissaries (wuwen shizhe 五瘟使者). ${ }^{37}$ Scattered mention of these figures and other elements associated with the Double Fifth festival can be found within

$32 \quad$ Ibid., 356c28-357a3.

33 Such accounts can mostly be found in the Song gaoseng zhuan 宋高僧傳, T. no. 2061.

34 Strickmann 2002.

35 See Unschuld $1985,29-5$ o, on "demonic" etiologies and 117-31 on ethico-religious etiologies. See also von Glahn 2002, 98-129.

36 On the Double Fifth festival, see Bodde 1975, 289-316; Katz 1995, 39-75.

37 Von Glahn 2004, 115-22; Katz 1995, 50-58. 
Chan Buddhist texts from the Song onward. The Recorded Discourses of Chan Master Fayan describes a short sermon that Fayan 法演 (d. 1104) gave on the Double Fifth, in which he announces that he possesses a "divine talisman" (shenfu 神符) that can bring peace to the court, the government officials, the common people, and the realm. He is then visited by a "talisman envoy" ( fushi 符使) who announces that all these matters have been handled, but complains about the arrogance and intractability of Chan monks. Fayan agrees and sends the envoy off with a verse. ${ }^{38}$ This story does not specifically mention plague spirits, but the date of the sermon and the references to the "divine talisman" and the "talisman envoy" - a type of supernatural being invoked in Daoist rites who carries out the talisman-holder's commands-evoke the imagery of the Double Fifth exorcisms.

A more explicit connection is made in the Recorded Discourses of Chan Master Yuanwu Foguo, who had trained under Fayan. After Yuanwu 圓悟 (10631135) ascends to his seat in the lecture hall on one Double Fifth, he delivers a short verse describing the bounties of midsummer. Immediately after that,

suddenly a talisman envoy appeared and said, "Down the mountain, the five plague [demons] are spreading severe epidemics everywhere. I came to you, Reverend, seeking a divine talisman so that I can go drive them off." The monk took his staff and drew a circle. Suddenly, [the envoy] disappeared. Shortly after, he returned and said, "The five plague demons have been driven away to another realm. I just have one matter to ask you, Reverend. Where did you get a talisman with such numinous efficacy?" The monk struck him on the back, and he immediately disappeared with no trace or echo. Then [the master] left without saying another word. ${ }^{39}$

Another sermon given by Yuanwu on the Double Fifth is similarly filled with exorcistic allusions. Yuanwu addresses the hall, saying,

The fifth day of the fifth month is the Heavenly Apex Festival, when the myriad gremlins and imps are all eradicated.... Zhong Kui and his little sister dance on the three platforms, while eight-armed Nața chews on iron ore. It is commanded! Capture! Behead! Quickly, quickly, in accordance with the statutes and ordinances ${ }^{40}$

38 Fayan chanshiyulu 法演禪師語錄, T. no. 1995, 47:661a15-27.

39 Yuanwu Foguo chanshi yulu 圓悟佛果禪師語錄, T. no. 1997, 47:748a29-b11.

40 Ibid., 47:744a3-6. 
Zhong Kui 鍾馗 is a legendary exorcist whose cult flourished during the Song, and Nața 哪吒 is an Indic guardian figure associated with the subjugation of demons. ${ }^{41}$ Moreover, the commands "Capture! Behead! Quickly, quickly ..." and so forth are common utterances in Daoist exorcistic rituals. We find a similar constellation of symbols in the Recorded Discourses of Monk Rujing (1163-1228), which relates that, during a lecture, Rujing 如淨 "drew a circle with his whisk and said, 'See here, I have drawn a divine talisman. What do you think - should we hang it up at the ghosts' gate? The red-mouthed, white-tongued [demons] will all be eradicated."'42

These stories portraying Chan monks as engaging exorcistic activities usually associated with Daoists and folk religious specialists are somewhat tonguein-cheek. The circle that Yuanwu and Rujing draw is an important symbol for Chan Buddhists, representing the total unity of all phenomena. ${ }^{43}$ By calling their circles "divine talismans," they slyly poke fun at their Daoist counterparts, who are well known for their use of talismans in exorcistic rites around the Double Fifth, while also suggesting that their own supernatural abilities equal those of the Daoists. However, despite their satirical tone, these accounts also demonstrate that these Chan monks were quite familiar with the customs and rituals associated with the Double Fifth.

Evidence from other texts shows that Buddhists did actually engage in exorcistic practices associated with the Double Fifth. The Record of Excellent Discourses Collected from Master Yin of the Longquan Hall at Mt. Gaofeng, a collection of liturgical texts compiled around 1287 by the disciple of a monk named Deyin 德因 (fl. thirteenth century), contains a "Boat-Dispatching Writ" (遣舡 文) intended for use in a well-known Double Fifth ritual that involved expelling plague demons by sending them off on a burning boat. ${ }^{44}$ The writ reads:

We supplicate to the sages who oversee the heavens, the officials of the Plague Bureau with their great numinous powers. Hordes of ghosts have amassed, and the plague troops have received the talisman of the Golden Porte of Purple Tenuity. Carrying out the commands of the Most High Jade Emperor, they patrol throughout the world investigating the human realm, eliminating those with wicked minds and commending those who attend to virtue. Releasing the powerful winds, the plague winds

\footnotetext{
41 On Zhong Kui, see Idema and West 2016. On Nața, see Shahar 2013.

42 Rujing heshang yulu 如淨和尚語錄, T. no. 2002A, 48:124a19-22.

43 This symbolism is particularly associated with the well-known "ox-herding pictures" used as a teaching device in Chinese Chan (and Japanese Zen) from the Song dynasty onward. See Despeux 1981. 
quickly spread as their delight turns to anger in a second. Fanning the deathly pneumas, the poisonous vapors spread vigorously, appearing and disappearing in an instant. Their supernatural powers produce unceasing transformations as they examine thousands of cases and implement hundreds of different solutions. Meeting virtuous people, they clasp and salute with their hands, bestowing fortune and blessings. Encountering wicked-minded people, they become enraged and furiously send down disasters and calamities. Respectfully, we pray that ... [they] will rein in the plague pneumas and transform them to auspicious vapors, gather up all the plague winds and create gales of auspiciousness.

Following the instructions left behind by our Buddha, we have all come on this pleasant evening to participate in a Dharma gathering.... Today, so-and-so has arranged this wonderful gathering and set out this Dharma feast. In particular, they have prepared a beautifully decorated boat to offer as a special gift. This boat was made by expert artisans and skillfully adorned. Carved with dragons and phoenixes, tigers' heads and leopards' tails, inwardly it contains a thousand years of provisions, while externally it can cover countless leagues of watery terrain.... Rein in the plague [spirits], capture the poisonous [vapors], and place them all on the dragon boat. As we beat the drum and unfurl the sail, let everyone go back the way that they came. ${ }^{45}$

Similarly, the seventeenth-century Critical Edition of Liturgical Writings for Chan Monasteries contains two short prayers for averting plagues that, while not specific to the Double Fifth, contain language addressing the Plague Bureau, praying that its officials will forgive the offenses of the sick people and stop the plague pneumas from spreading. ${ }^{46}$

On first glance, these Chan texts are quite different from other Buddhist writings about epidemics and plague that we have seen above. They draw upon indigenous notions of the cosmos as a divine bureaucracy, ${ }^{47}$ addressing prayers to the divine officials of the Plague Bureau (wenbu 瘟部) in hopes that they will withdraw their legions of plague troops. Yet despite the different imagery and language used in these plague-quelling texts, they are still premised on the idea that supernatural beings transmit infectious diseases to punish people for their ethical transgressions. The means that they employ to combat these

45 Gaofeng longquan yuan Yinshi jixian yulu 高峰龍泉院因師集賢語錄, X. no. 1277, 65:37 $\mathrm{b}_{7}-\mathrm{c} 5$.

46 Chanlin shuyu kaozheng 禪林疏語考證, X. no. 1252, 63:694a16-c1.

47 Wolf 1974. 
diseases - repentance, meritorious activities, and ritual exorcism-are the same as those found in the Indic sources discussed above.

\section{Conclusion}

Sinitic Buddhist texts generally claim that epidemics result from some combination of moral retribution and ghostly intervention, and are to be treated accordingly. Hagiographical accounts confirm that techniques such as repentance, devotional merit-making, incantations, and ritual exorcism were regarded as viable ways to address the spread of infectious disease. However, the Chan texts and prayers associated with the Double Fifth demonstrate that Chinese Buddhists often assimilated these practices of Indic origin to indigenous Chinese paradigms.

\section{About the Author}

Joshua Capitanio received his $\mathrm{PhD}$ in East Asian languages and civilizations from the University of Pennsylvania and is currently the public services librarian at the East Asia Library, Stanford University. His research focuses on notions of salvation and self-cultivation in late medieval Buddhist and Daoist ritual practices.

\section{Bibliography}

\section{Primary Sources}

Shinsan Dainihon zokuzōkyō 新纂大日本續藏經. 1975-89. Edited by Watanabe Kōshō 河村孝照. Tokyo: Kokusho Kankōkai.

Taishō shinshū daizōkyō 大正新修大藏經. 1924-32 (-1935). Edited by Takakusu Junjirō 高楠順次郎 and Watanabe Kaikyoku 渡辺海旭. Tokyo: Taishō Issaikyō Kankōkai.

\section{Secondary Sources}

Birnbaum, Raoul. 1979. The Healing Buddha. Boston, MA: Shambhala.

Bodde, Derk. 1975. Festivals in Classical China: New Year and Other Annual Observances During the Han Dynasty, 206 B.C.-A.D. 220 . Princeton, NJ: Princeton University Press. Demiéville, Paul. 1985. Buddhism and Healing: Demiéville's Article “Byō” from Hōbōgirin. Translated by Mark Tatz. Lanham, MD: University Press of America. 
Despeux, Catherine. 1981. Le chemin de l'éveil. Paris: L’Asiathèque.

Hanson, Marta. 2011. Speaking of Epidemics in Chinese Medicine: Disease and the Geographic Imagination in Late Imperial China. New York: Routledge.

Hureau, Sophie. 2010. "Buddhist Rituals." In Early Chinese Religion, Part Two: The Period of Division (220-589AD), edited by John Lagerwey and Lü Pengzhi, 12O7-44. Leiden: Brill.

Idema, Wilt L., and Stephen H. West. 2016. "Zhong Kui at Work: A Complete Translation of The Immortal Officials of Happiness, Wealth, and Longevity Gather In Celebration, by Zhu Youdun (1379-1439)." Journal of Chinese Religions 44, no. 1: 1-34.

Katz, Paul R. 1995. Demon Hordes and Burning Boats: The Cult of Marshal Wen in Late Imperial Chekiang. Albany: State University of New York Press.

Kuo, Li-ying. 1994. Confession et contrition dans le bouddhisme chinois du Ve au Xe siècle. Paris: École française d'Extrême-Orient.

Kuriyama, Shigehisa. 200o. "Epidemics, Weather, and Contagion in Traditional Chinese Medicine." In Contagion: Perspectives from Pre-Modern Societies, edited by Lawrence I. Conrad and Domink Wujastyk, 3-22. New York: Routledge.

La Vallée Poussin, Louis de. 1988. Abhidharmakośabhāṣyam. Translated by Leo M. Pruden. Berkeley, CA: Asian Humanities Press.

Leung, Angela Ki Che. 1993. "Diseases of the Premodern Period in China." In The Cambridge World History of Human Disease, edited by Kenneth F. Kiple, 354-62. Cambridge: Cambridge University Press.

Levering, Miriam. 1989. "Scripture and its Reception: A Buddhist Case." In Rethinking Scripture, edited by Miriam Levering, 58-101. Albany: State University of New York Press.

McBride, Richard D., III. 2005. "Dhāraṇī and Spells in Medieval Sinitic Buddhism." Journal of the International Association of Buddhist Studies 28, no. 1: 85-114.

Nattier, Jan. 1991. Once Upon a Future Time: Studies in a Buddhist Prophecy of Decline. Berkeley, CA: Asian Humanities Press.

Needham, Joseph, and Lu Gwei-Djen, eds. 200o. Science and Civilisation in China. Vol. 6, Biology and Biological Technology, Part 6: Medicine, edited by Nathan Sivin. Cambridge: Cambridge University Press.

Rahula, Walpola. 2001. Abhidharmasamuccaya: The Compendium of the Higher Teaching (Philosophy) by Asanga. Translated by Sara Boin-Webb. Fremont, CA: Asian Humanities Press.

Salguero, C. Pierce. 2013. "Fields of Merit, Harvests of Health: Some Notes on the Role of Medical Karma in the Popularization of Buddhism in Early Medieval China." Asian Philosophy 23, no. 4: 341-49.

Salguero, C. Pierce. 2014. Translating Buddhist Medicine in Medieval China. Philadelphia: University of Pennsylvania Press. 
Shahar, Meir. 2013. "Indian Mythology and the Chinese Imagination: Nezha, Nalakūbara, and Kṛșna." In India in the Chinese Imagination: Myth, Religion, and Thought, edited by John Kieschnick and Meir Shahar, 21-45. Philadelphia: University of Pennsylvania Press.

Strickmann, Michel. 1990. "The Consecration Sūtra: A Buddhist Book of Spells." In Chinese Buddhist Apocrypha, edited by Robert E. Buswell, Jr., 75-118. Honolulu: University of Hawai'i Press.

Strickmann, Michel. 2002. Chinese Magical Medicine. Stanford, CA: Stanford University Press.

Unschuld, Paul U. 1985. Medicine in China: A History of Ideas. Berkeley: University of California Press.

von Glahn, Richard. 2004. The Sinister Way: The Divine and the Demonic in Chinese Religious Culture. Berkeley: University of California Press.

Wolf, Arthur P. 1974. "Gods, Ghosts, and Ancestors." In Religion and Ritual in Chinese Society, edited by Arthur P. Wolf, 131-82. Stanford, CA: Stanford University Press.

Zürcher, Erik. 1982. "Prince Moonlight: Messianism and Eschatology in Early Medieval Chinese Buddhism." T'oung Pao, 2nd ser., 68, no. 1/3: 1-75. 